\title{
PROFIL ASAM LEMAK DAGING BABI BALI ASLI DAN BABI LANDRACE
}

\author{
SRIYANI, N. L. P., M. A. RASNA., I N. A. ARIANA DAN A. W. PUGER \\ Fakultas Peternakan Universitas Udayana \\ e-mail: sriyaninlp@yahoo.co.id
}

\begin{abstract}
ABSTRAK
Tujuan penelitian ini adalah untuk mengetahui perbedaan profil lemak hewani dari dua jenis daging babi dari bangsa (breed) yang berbeda yaitu babi bali asli (babi lokal) dan babi landrace (babi ras). Penelitian ini dilaksanakan dengan mengambil beberapa sampel daging babi bali dan babi Landrace. Daging yang diambil bersumber dari daging yang dijual di Rumah Potong Hewan Tradisional yang berlokasi di Banjar Pegending, Desa Dalung Kuta Utara. Selanjutnya sampel daging dianalisis profil asam lemaknya dengan metode Gas Cromatografi di Laboratorium Terpadu IPB Bogor. Hasil dari penelitian ini menunjukkan bahwa profil asam lemak penyusun daging babi bali asli maupun daging babi landrace terdiri dari 10 asam lemak jenuh (Saturated Fatty Acids/SFA) yaitu asam caprik, asam laurat, asam miristat, asam pentadecanoat, asam palmitat, asam heptadecanoat, asam stearat, asam arachidat, asam behenik, asam caprilic, empat jenis asam lemak tidak jenuh tunggal (Mono Unsatured Fatty Acids/MUFA) yaitu asam palmitoleat, asam oleat, asam erucic, asam eiucosenoic dan 2 jenis asam lemak tak jenuh ganda (Polly Ansatured Fatty Acids/PUFA) yaitu asam linoleat, asam eicosedienoic.
\end{abstract}

Kata kunci: profil asam lemak, daging babi bali, dan babi landrace

\section{PROFILE AND FATTY ACID CHARACTERISTICS OF BALI PIG AND LANDRACE MEAT}

\begin{abstract}
The purpose of this study is to determine the differences of profile and characteristics of fatty acid on bali pig and landrace's pork. Meat samples are taken from the traditional slaughter housing at Banjar Pegending, Dalung, North Kuta. The fatty acid was analyzed from meat sample with Cromatography Gas method at Bogor Agriculture Institute Laboratorium. The result of study showed that profile of fatty acid forms consists of 10 Saturated Fatty Acids/SFA. They are capric acid, lauric acid, myristic acid, pentadecanoic acid, palmitic acid, heptadecanoic acid, stearic acid, arachidic acid, behenic acid and caprilic acid. Four mono unsaturated fatty acids (MUFA) are palmitoleic acid, oleic acid, erucic acid, and eiucosenoic acid. Two poly unsaturated fatty acids (PUFA) are linoleic acid and eicosedienoic acid. The differences of pork taste caused by different content of fatty acids. The flavor of bali's pork caused by higher content of oleic acid compared to Landrace pork.
\end{abstract}

Key word: profile fatty acid, bali pig'and landrace meat

\section{PENDAHULUAN}

Penyediaan pangan, termasuk pangan asal hewan akan menjadi tantangan bagi sejumlah negara di dunia. Hal ini disebabkan kecepatan perkembangan jumlah penduduk, meningkatnya kesadaran gisi masyarakat dan meningkatnya pendapatan penduduk per kapita. Kalau kita cermati arah kebijakan Dirjen Peternakan dan Kesehatan Hewan pasca tahun 2014, tampaknya terjadi perubah strategi dari pendekatan swasembada menjadi pemenuhan kebutuhan bahan pangan pokok.
Untuk itu sasaran yang harus dicapai kaitannya dengan budidaya ternak adalah bagaimana produksi dan populasi ternak bisa ditingkatkan. Program pemerintah ini juga menekankan pembangunan sektor peternakan melalui peternakan tangguh berbasis pada sumberdaya lokal (Dirjennak dan Keswan, 2010). Salah satu ternak lokal dan merupakan plasma nuftah pulau Bali yang potensial dikembangkan sebagai sumber pangan hewani adalah ternak babi bali.

Pulau Bali pada umumnya, sebagian besar masyarakat mengkonsumsi daging babi. Hal ini bisa dimaklumi 
karena sebagian besar dari masyarakatnya adalah penganut agama Hindu yang tidak mengharamkan daging babi untuk dikonsumsi. Daging babi yang beredar di pasar tradisional kota Denpasar pada umumnya berasal dari daging babi dari bangsa babi landrace. Sangat sedikit ditemukan daging babi yang berasal dari breed babi bali (lokal). Beberapa permasalahan pada pemeliharaan babi lokal antara lain kecepatan produksi yang relatif lebih rendah dibandingkan bangsa babi landrace dan penyediaan bibit yang terbatas menjadi penyebab langkanya peredaran daging babi bali di pasarpasar tradisional. Namun daging babi bali memiliki segmen pasar/konsumen yang khusus terutama bagi konsumen yang menggunakan babi bali sebagai sarana upacara misalnya untuk pembuatan guling babi dan kuliner lainnya yang berasal dari daging babi. Beberapa konsumen yang masih setia terhadap daging babi bali menyatakan pendapatnya bahwa daging babi bali memiliki cita rasa yang jauh lebih gurih dibandingkan daging babi landrace.

Daging adalah salah satu produk peternakan yang potensial sebagai sumber protein hewani asal ternak. Disamping protein, daging juga mengandung lemak. Lemak adalah salah satu komponen makanan multifungsi yang sangat penting untuk kehidupan. Selain memiliki sisi positif, lemak juga mempunyai sisi negatif terhadap kesehatan. Asupan lemak jenuh dalam jumlah banyak akan meningkatkan kadar kolesterol darah yang berarti juga meningkatkan resiko arterosklerosis dan selanjutnya dapat meningkatkan resiko penyakit jantung koroner. Sebagaian besar penelitian mengenai asam lemak jenuh yang dikaitkan dengan penyakit kardiovaskuler, biasanya menggunakan asam lemak jenuh hewani yang merupakan asam lemak jenuh rantai panjang. Adanya kekwatiran akan produk peternakan terhadap kandungan lemak khususnya lemak jenuh perlu menjadi perhatian dalam pemilihan produk ternak misalnya dalam memilih daging yang bersumber bangsa ternak yang berbeda.

Mengacu dari permasalahan tersebut di atas maka peneltian ini dilakukan untuk melihat perbedaan profil dan karakteristik lemak hewani yang terdapat pada daging babi dari dua jenis yaitu babi bali dan babi landrace.

\section{MATERI DAN METODE}

\section{Materi}

Materi dalam penelitian ini adalah daging dari otot longisimus dorsi (LD), dari ternak babi yang memiliki umur dan jenis kelamin yang sama tetapi dengan bangsa (breed) yang berbeda. Sampel ternak tersebut berasal dari ternak babi bali asli dan babi Landrace. Ternak babi bali berasal dari babi yang dipelihara secara tradisonal di Kecamatan Grokgak, Kabupaten Buleleng dan ternak babi Landarce yang dipelihara secara intensif di Banjar Pegending, Desa Dalung, Kecamatan Kuta Utara, Kabupaten Badung.

\section{Lokasi}

Pemotongan ternak dilaksanakan di tempat pemotongan hewan tradisional (RPH) di Banjar Pegending Mengwi Kabupaten Badung. Setelah sampel daging diambil dilanjutkan dengan analisis profil asam lemak daging di Lab Terpadu Institut Pertanian Bogor.

\section{Prosedur Analisis Profil Asam Lemak dengan Metode Gas Cromatografi}

Analisis komposisi asam asam lemak dari masing masing sampel daging yang telah diekstrak dilakukan menurut prosedur AOAC (1990). Prosedur analisis dilakukan dengan bantuan instrumen kromatografi gas (GC) dari tipe GC-9AM Shimadzu dan tipe Hewlett Packard (Hp) 6890 series.

Diawali dengan mengekstrak lemak sampel daging dengan heksana selama \pm 6 jam. Sampel lemak ditimbang sebanyak 20-30 mg dan dimasukkan ke dalam tabung bertutup teflon. $1 \mathrm{~mL} \mathrm{NaOH} \mathrm{o,5} \mathrm{N}$ ditambahkan dalam metanol dan dipanaskan dalam penangas air selama 20 menit. Selanjutnya $2 \mathrm{ml} \mathrm{BF}_{3} 16 \%$ dan $5 \mathrm{mg} / \mathrm{ml}$ standar internal, dipanaskan selama 20 menit. Kemudian ditambahkan $2 \mathrm{ml} \mathrm{NaCI}$ jenuh dan $1 \mathrm{ml}$ heksana, kocok dengan baik. Lapisan heksana dengan bantuan pipet tetes dipindahkan ke dalam tabung yang berisi 0,1 $\mathrm{g} \mathrm{Na}_{2} \mathrm{SO}_{4}$ anhidrat, dan dibiarkan 15 menit selanjutnya diinjeksikan ke kromatografi gas.

Sebanyak $1 \mu$ pelarut diinjeksikan ke dalam kolom. Bila aliran gas pembawa dan sistem pemanasan sempurna, puncak pelarut akan nampak dalam waktu kurang dari 1 menit. Setelah pena kembali ke nol (baseline) $5 \mu \mathrm{l}$ campuran standar FAME diinjeksikan. Bila semua puncak sudah keluar, $5 \mu \mathrm{l}$ sampel yang telah dipreparasi (A) diinjeksikan. Waktu retensi dan puncak masing-masing komponen diukur. Jika rekorder dilengkapi dengan integrator, waktu retensi dan luas puncak langsung diperoleh dari integrator. Waktu retensi dengan standar dibandingkan untuk mendapatkan informasi mengenai jenis dari komponen-komponen dalam sampel. Untuk metode standar internal, jumlah masing-masing komponen dalam sampel dapat dihitung dengan cara sebagai berikut:

$$
\begin{aligned}
& \quad \mathrm{CX}=\frac{\mathrm{Ax} \cdot \mathrm{R} \mathrm{CS}}{\mathrm{A}_{\mathrm{S}}} \\
& \text { Keterangan: } \\
& \mathrm{CX}=\text { Konsentrasi komponen } \mathrm{x} \\
& \mathrm{C}_{\mathrm{S}}=\text { Konsentrasi standar internal } \\
& \mathrm{A}_{\mathrm{x}}=\text { Luas puncak komponen } \mathrm{x} \\
& \mathrm{A}_{\mathrm{S}}=\text { Luas puncak standar internal } \\
& \mathrm{R}=\text { Respon detektor terhadap komponen } \mathrm{x} \text { relatif terhadap standar }
\end{aligned}
$$




\section{Rancangan penelitian}

Pada penelitian ini, rancangan yang digunakan yaitu rancangan acak lengkap (RAL). Perlakuan adalah jenis babi yang berbeda babi bali dan babi landrace masingmasing perlakuan terdiri dari enam ulangan sampel daging.

\section{Analisis Statistik}

Data yang diperoleh dianalisis menggunakan Two Independent Sample T test (Steel dan Torrie, 1989).

\section{HASIL DAN PEMBAHASAN}

Hasil dari penelitian ini menunjukkan bahwa profil asam lemak penyusun daging babi bali yang teridentifikasi dalam penelitian ini adalah 15 (lima belas) macam asam lemak yaitu asam asam caprik (C10:0), asam laurat (C12:0), asam miristat (C14:0), asam pentadecanoat $\left(\mathrm{C}_{15}: 0\right)$, asam palmitat (C16:0), asam heptadecanoat (C17:0), asam stearat (C18:0), asam arachidat (C20:0), asam behenik (C22:0), asam palmitoleat (C16:1), asam oleat (C18:1), asam erucic (C22:1), asam eiucosenoic (C20:1) asam linoleat (C18:2), asam eicosedienoic (C20:2) (Tabel 4.1). Sementara asam lemak penyusun daging babi landrace ada 16 (enam belas) yaitu semua asam lemak penyusun daging babi bali ditambah denga asam caprilat (C8 :0) (Tabel 1). Asam caprilat (C8:0) tidak teridentifikasi pada sampel daging babi bali. Sebagian besar kandungan dari asam lemak penyusun dari kedua jenis daging babi lokal dan babi landrace secara statistik tidak berbeda nyata $(\mathrm{P}>0,05)$ kecuali pada kandungan asam asam eiucosenoic (C20:1) pada daging babi lokal secara statistik nyata lebih tinggi daripada daging babi landrace $(\mathrm{P}<0,05)$ Tabel 1 .

Karakteristik asam lemak daging babi bali dan babi landrcae adalah kandungan asam lemak jenuh (SFA) daging babi bali 28,79\% terdiri dari caprik (C10:0) o,06\% asam laurat (C12:0) 0.14\%, asam miristat (C14:0) 1,03\%, asam pentadecanoat $(\mathrm{C} 15: 0) 0,03 \%$, asam palmitat (C16:0) 18,53\%, asam heptadecanoat (C17:0) 0,17\%, asam stearat (C18:0) 8,68\%, asam arachidat (C20:0) 0,12\%, asam behenik (C22:0) 0,04\%. Kandungan asam lemak jenuh daging babi landrace (SFA) 29,26\% terdiri dari asam kaprilat (C8:0) 0,074\%, caprik (C10:0) 0,07\%, asam laurat (C12:0) 0,06\%, asam miristat (C14:0) $0,82 \%$, asam pentadecanoat $\left(\mathrm{C}_{15}: 0\right) \mathrm{0}, 05 \%$, asam palmitat (C16:0) 19,22\%, asam heptadecanoat (C17:0) 0,25\%, asam stearat (C18:0) 8,58\%, asam arachidat (C20:0) 0,12\%, asam behenik (C22:0) 0,04\%.

Kandungan asam lemak tidak jenuh tunggal (MUFA) daging babi bali 34,31\% terdiri asam palmitoleat (C16:1) 1,99\%, asam oleat (C18:1) 31,23\%, asam erucic (C22:1) 0,07\%, asam eiucosenoic (C20:1) 1,01\%. Sementara daging babi landrace sebesar 30,60 \% terdiri dari asam
Tabel 1. Perbedaan profil dan karakteristik asam lemak daging babi bali dan babi landrace

\begin{tabular}{|c|c|c|c|c|}
\hline No & Profil asam lemak & $\begin{array}{l}\text { Daging babi } \\
\text { bali \%/fat }\end{array}$ & $\begin{array}{c}\text { Daging babi } \\
\text { landrace \%/ } \\
\text { fat }\end{array}$ & SEM \\
\hline 1 & Caprilic acid C8:0 & nd & 0,074 & - \\
\hline 2 & Capric acid C10:0 & $0,06^{a}$ & $0,07^{a}$ & 0,003 \\
\hline 3 & Lauric Acid, C12:0 & $0,14^{a}$ & $0,06^{a}$ & 0,005 \\
\hline 4 & Myristic Acid C14:0 & $1,03^{a}$ & $0,82^{a}$ & 0,026 \\
\hline 5 & Pentadecanoic Acid C15:0 & $0,03^{a}$ & $0,05^{a}$ & 0,002 \\
\hline 6 & Palmitic Acid C16:0 & $18,53^{a}$ & $19,22^{a}$ & 0,446 \\
\hline 7 & Heptadecanoic Acid, C17:0 & $0,17^{a}$ & $0,25^{a}$ & 0,100 \\
\hline 8 & Stearic Acid, C18:0 & $8,68^{a}$ & $8,58^{a}$ & 0,428 \\
\hline 9 & Arachidic Acid, C20:0 & $0,12^{a}$ & $0,12^{a}$ & 0,004 \\
\hline 10 & Behenic Acid, C22:0 & $0,04^{a}$ & $0,04^{a}$ & 0,004 \\
\hline & $\begin{array}{l}\text { Saturated Fatty Acid/SFA } \\
\text { (Lemak Jenuh) }\end{array}$ & 28,79 & 29,26 & \\
\hline 11 & Palmitoleic Acid,C:16:1 & $1,99^{a}$ & $1,15^{a}$ & 0,078 \\
\hline 12 & Oleic Acid C18:1n & $31,23^{a}$ & $28,70^{a}$ & 0,078 \\
\hline 13 & Erucic Acid, C22:1n & $0,07^{a}$ & $0,04^{a}$ & 0,014 \\
\hline 14 & Cis:11- Eicosenoic Acid, C20:1 & $1,01^{a}$ & $0,71^{b}$ & 0,042 \\
\hline & $\begin{array}{l}\text { Mono Unsaturated Fatty Acid/ } \\
\text { MUFA (Lemak Tak Jenuh Tunggal) }\end{array}$ & 34,31 & 30,60 & \\
\hline 15 & Lonoleic Acid C18:2n & $10,94^{a}$ & $12,15^{a}$ & 0,565 \\
\hline 16 & Eicosedienoic Acid, C20:2 & $0,55^{a}$ & $0,42^{a}$ & 0,130 \\
\hline & $\begin{array}{l}\text { Poly Unsaturated Fatty Acid/PUFA } \\
\text { (Lemak Tak Jenuh Ganda) }\end{array}$ & 11,49 & 12,57 & \\
\hline
\end{tabular}

palmitoleat (C16:1) 1,15\%, asam oleat (C18:1) 28,70\%, asam erucic (C22:1) 0,04\%, asam eiucosenoic (C20:1) $0,71 \%$. Kandungan asam lemak tidak jenuh ganda (PUFA) daging babi bali 11,49\% terdiri dari asam linoleat (C18:2) 10,94\%, asam eicosedienoic (C20:2) 0,55\%. dan daging babi landrace $12,57 \%$. terdiri dari asam linoleat (C18:2) 12,15\%, asam eicosedienoic (C20:2) 0,42\%.

Kandungan asam lemak jenuh yang dominan pada daging babi bali dan daging babi landrace adalah asam palmitat (C16:0) dan asam stearat (C18:0). Kandungan asam lemak ini pada daging kedua bread babi secara statistik tidak berbeda nyata. Hal ini menunjukkan bahwa babi dengan jenis yang berbeda dan cara pemeliharaan yang berbeda tidak memberikan pengaruh terhadap kandungan asam lemak palmitat dan stearat. Babi bali pada umumnya diberikan makanan apa adanya yang berasal dari pakan lokal dan limbah rumah tangga. Dari hasil wawancara dengan beberapa peternak yang memelihara babi bali makanan babi terdiri dari batang pisang, daun lamtoro, daun gamal, daun kelor daun mengkudu, bungkil kelapa (usam) dan kadang-kadang di tambah dengan dedak. Komposisi bahan pakan tersebut berbeda beda setiap harinya tergantung dari ketersediaan pakan tersebut di lingkunan sekitar. Semua bahan makanan tersebut di campur dengan limbah dapur (banyu) dengan direbus atau tanpa direbus terlebih dahulu sebelum diberikan ternak babinya. Sedangkan babi landrace di pelihara dengan intensif dan di berikan pakan konsentrat. 
Beberapa asam lemak jenuh yang lain terditeksi dalam jumlah yang kecil dan kandungannya dalam daging kedua bread ini secara statistik tidak berpengaruh nyata. Total asam lemak jenuh saturated faty acid (SFA) secara kuantitatif pada daging babi bali $28,79 \%$, angka ini lebih rendah daripada kandungan asam lenak jenuh daging babi landrace sebesar 29,26\%. Kandungan asam lemak tak jenuh tunggal monounsaturated faty acid (MUFA) yang dominan pada daging babi bali maupun daging babi landracae adalah asam lemak oleat (C18:1). Kandungan asam lemak ini secara statistik tidak berpengaruh nyata antara daging babi bali dan daging babi landrace. Walaupun secara statistik tidak berbeda nyata akan tetapi secara kuantitatif kandungan asam oleat daging babi bali lebih tinggi daripada daging babi landrace. Kandungan asam lemak tak jenuh ganda (PUFA) daging babi bali $11,49 \%$ dan babi landrace $12,57 \%$ secara statistik tidak berbeda nyata. Secara kuantitatif kandungan PUFA daging babi bali lebih kecil daripada daging babi landrace.

Sifat kimia daging (termasuk komposisi asam lemak) bervariasi tergantung dari spesies hewan, umur, jenis kelamin, pakan serta serta lokasi anataomis dan fungsi bagian bagian otot dalam tubuh (Romans et al., 1994). Pada penelitian ini kedua jenis daging babi yang berasal dari bangsa yang berbeda kandungan profil asam lemak sebagian besar secara secara statistik tidak berbeda nyata kecuali pada asam lemak eicosenoic. Dari hal tersebut dapat diartikan bahwa secara statistik kedua babi dari bangsa yang berbeda dengan manajemen pemeliharaan yang berbeda tidak menghasilkan kandungan asam lemak dalam produk dagingnya secara nyata. Babi bali pada umumnya dipelihara dengan sistem tradisional dengan cara ektensif atau diumbar dengan makanan yang berasal dari limbah rumah tangga yang di bali di sebut dengan banyu, batang pisang, daun lamtoro, daun gamal, daun kelor, bungkil kelapa (usam) daun mengkudu dan lain sebagainya (berdasarkan hasil wawancara dengan peternak). Menurut Budaarsa et al. (2016), hasil pengamatan lapangan pada pada sistem pemeliharaan babi bali disimpulkan, bahwa sebagian besar (85\%) peternak babi bali memberikan dedak padi dan batang pisang sebagai pakan utama. Cara pemberian pakan ada yang dimasak dan tidak dimasak. Pakan tambahan yang diberikan berupa limbah dapur. Sementara babi landrace dipelihara dengan intensif, dengan dikandangkan dan pakan berupa konsentrat.

Walaupun secara statistik kandungan profil asam lemak dari kedua jenis daging babi tersebut berbeda tidak nyata akan tetapi secara kuantitatif kandungannya berbeda. Perbedaan kandungan dan jumlah profil asam lemak penyusun kemungkinan besar menjadi penyebab perbedaan cita rasa pada kedua daging babi tersebut. Dalam teknologi makanan lemak (kandungan maupun profil asam lemaknya) memegang peranan penting yang memberikan rasa gurih dan aroma yang spesifik. Lemak juga memberikan konsistensi yang empuk dan halus, yang menyebabkan meningkatnya cita rasa makanan (Sudarmadji et al., 1997).

\section{SIMPULAN}

Dari hasil penelitian ini dapat disimpulkan bahwa profil asam lemak penyusun daging babi bali dan daging babi landrace adalah sama, terdiri dari sepuluh asam lemak jenuh, empat asam lemak tak jenuh tunggal dan dua asam lemak tak jenuh ganda. Kandungan asam lemak tersebut secara statistik tidak berbeda nyata, namum secara kuantitatif asam lemak jenuh pada daging babi bali lebih rendah daripada daging babi landrace dan asam lemak tak jenuh pada daging babi bali lebih tinggi daripada daging babi landrace.

\section{UCAPAN TERIMA KASIH}

Penulis menyampaikan ucapan terimakasih kepada Rektor Universitas Udayana dan Ketua Lembaga Penelitian dan Pengabdian Kepada Masyarakat atas pendanaan penelitian ini. Terimakasih pula penulis sampaikan kepada staf Lab Terpadu IPB yang telah membantu menganalisis profil asam lemak daging dan pemilik RPH tradisional Bapak I Wayan Patra yang telah mengijinkan dalam pengambilan sampel penelitian.

\section{DAFTAR PUSTAKA}

AOAC. 1990. Offcial Method of Analysis. 13th Ed. Association of Offcial Analytical Chemist. Washington, DC.

Budaarsa, K., A.W. Puger, dan I M. Suasta. 2016. Ekplorasi komposisi pakan tradisional babi bali. Majalah Ilmiah Peternakan Volume 19 No 1 Tahun 2016.

Direktorat Jenderal Peternakan dan Kesehatan Hewan Kementerian Pertanian Republik Indonesia , 2010. Rencana Strategis (Renstra) Direktorat Jenderal Peternakan dan Kesehatan Hewan Tahun 2010-2014.

Romans, J.R., W.J. Costello, C.W. Carlson, M.L. Greaser dan K.W. Jones. 1994. The Meat We Eat. Interstate Publishers, Inc. Danville, Illinois.

Steel, R.G.D. Ang J. H. Torrie. 1989. Principles and Procedures of Statistic. McGraw-Hill Book Co. Inc., New York.

Sudarmadji, S., Bambang Haryono, Suhardi 1997. Prosedur Analisis Untuk Bahan Makanan dan Pertanian. Penerbit Liberty. Yogyakarta. 